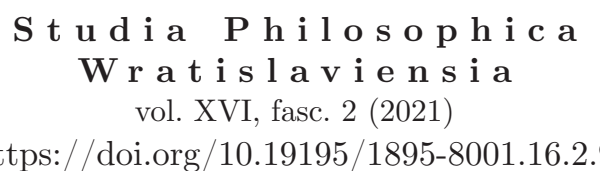

https://doi.org/10.19195/1895-8001.16.2.9

\author{
WOJCIECH SZCZERBA \\ ORCID: 0000-0003-2306-1562 \\ Ewangelikalna Wyższa Szkoła Teologiczna \\ Wrocław \\ Van Hügel Institute, St Edmund's College \\ University of Cambridge
}

\title{
Stworzenie z niczego, czyli słów kilka o monografii Jacka Zielińskiego Koncepcja creatio ex nihilo w myśli Apologetów greckich II wieku
}

\author{
Creation out of nothing. A few words on the monograph \\ of Jacek Zielinski, The Concept of Creatio ex Nihilo \\ in the Thought of Greek Apologists of the 2nd Century
}

\begin{abstract}
The monograph of Jacek Zielinski, The Concept of Creatio ex Nihilo in the Thought of the Greek Apologists of the 2nd century, published by Wroclaw's Atut in 2013, discusses an important problem of the theory of creation from nothing. It also asks an important question, how far the elements of the concept, articulated in its final form only by Augustine of Hippo can be found in the writings of the Christian apologists of the 2nd century. It is an important question, especially that the Bible in its canonical form, the early extra-biblical Jewish literature or - even more - Greek tradition does not unambiguously advocate the concept creatio ex nihilo. Hence the question how, when and why the concept was articulated, since it played such an important role in the Christian thought of later centuries. In addition, the book of Jacek Zielinski is important in Polish market, because there are only a few serious publications dealing with the issue. The article gives a description and short analysis of the book, pinpointing its strong sights and showing areas, which could be strengthened in this and - hopefully — following publications on creatio ex nihilo by Jacek Zieliński.
\end{abstract}

Keywords: creatio ex nihilo, Apologist, Biblical tradition, creation theories, the Bible, Augustin of Hippo, Judaism 
J. Zieliński, Koncepcja creatio ex nihilo w myśli Apologetów greckich II wieku, Oficyna Wydawnicza „Atut”, Wrocław 2013, ss. 427.

Teoria creatio ex nihilo jest koncepcją ważną na gruncie zarówno filozoficznym, jak i teologicznym. Wyraża ona podstawową ideę, że świat został powołany do istnienia przez Boga z niczego, ex nihilo. Zgodnie z chrześcijańskim ujęciem problemu Bóg, jako ostateczna przyczyna rzeczywistości, stworzył świat u zarania dziejów, wypowiadając Słowo-Logos (Rdz 1; Jn 1,1-3). Jest to wolny akt stwórczy (creatio), u podstaw którego leży miłość Boga, którego charakter określa Boża mądrość, który umożliwia Boża wszechmoc. Problem creatio podejmowany był, w taki czy inny sposób, od zarania chrześcijaństwa przez autorów ksiąg kanonicznych (na przykład Jn, Hbr), ojców apostolskich, apologetów czy — ogólnie rzecz ujmując — ojców Kościoła. Do określenia dojrzałej formy koncepcji w znaczący sposób przyczynił się Augustyn z Hippony, który dyskutując z myślą manichejską, w swoich komentarzach do Księgi Rodzaju wprost formułuje naukę o stworzeniu świata ex nihilo ${ }^{1}$. Problem stworzenia z niczego podejmuje między innymi Tomasz z Akwinu w Sumie przeciw poganom ${ }^{2}$, wskazując, że dzieło stworzenia zakłada wyłącznie istnienie Stwórcy, nie jest aktem koniecznym, ale opiera się na wolności, mądrości i wszechmocy Boga. Stworzone byty uczestniczą w Stwórcy, ale Stwórca w żaden sposób nie jest zależny od porządku stworzenia. Ostatecznie, nauka o stworzeniu świata z niczego znalazła swój wyraz w twierdzeniach Soboru laterańskiego IV z początku XIII wieku oraz Soboru Watykańskiego I z końca XIX wieku. Wypowiedzi te przytacza Katechizm Kościoła Katolickiego (n. 296) jako wyraz fundamentalnego przekonania chrześcijańskiej kosmologii ${ }^{3}$.

Książka Jacka Zielińskiego Koncepcja creatio ex nihilo w myśli Apologetów greckich II wieku wydana przez wrocławskie wydawnictwo Atut w 2013 podejmuje problem teorii stworzenia $\mathrm{z}$ niczego i zadaje pytanie, na ile ślady, elementy tej koncepcji w sposób pełny wyartykułowanej dopiero przez Augustyna z Hippony można odczytać w pismach chrześcijańskich apologetów II wieku. Pytanie wydaje się ze wszech miar zasadne, jako że ani Biblia w zachowanej formie kanonicznej, ani wczesna pozabiblijna literatura judaistyczna, ani tym bardziej tradycja grecka nie opowiada się jednoznacznie za koncepcją creatio ex nihilo, a niejednokrotnie wprost twierdzi: nihil ex nihilo, nic z niczego. W związku z tym powstaje pytanie, w jaki sposób, kiedy i dlaczego narodziła się koncepcja, która odegrała tak ważną rolę w myśli chrześcijańskiej późniejszych wieków. Dodatkowo książka Jacka Zielińskiego wydaje się ważna, wziąwszy pod uwagę fakt, że na wydawniczym rynku polskim niewiele jest opracowań na temat koncepcji stworzenia z niczego, szczegól-

${ }^{1}$ Por. św. Augustyn, Przeciwko Manichejczykom komentarz do Ksiegi Rodzaju, I, 3, 5 i 7, 11-12, [w:] św. Augustyn, Pisma egzegetyczne przeciw manichejczykom, tłum. J. Sulowski, Warszawa 1980, s. 25,29 .

${ }^{2}$ Por. Tomasz z Akwinu, Summa contra gentiles, II, 31-38. Wyd. polskie: św. Tomasz z Akwinu, Summa contra gentiles. Prawda wiary chrześcijańskiej $w$ dyskusji z poganami innowiercami i bładzacymi, tłum. Z. Włodek, W. Zega, Poznań 2003, s. 328-352.

3 http://www.vatican.va/archive/ENG0015/__P19.HTM (dostęp: 23.12.2018), http://www.katechizm.opoka.org.pl/rkkkI-2-1.htm (dostęp: 23.12.2018).

Studia Philosophica Wratislaviensia vol. XVI, fasc. 2, 2021

(C) for this edition by CNS 
nie w jej inicjalnej formie. W większości są to publikacje w postaci artykułów, fragmentów większych monografii lub krótkie noty. Zdecydowanie brakuje głębszych opracowań samej teorii creatio ex nihilo oraz koncepcji pochodnych, szczególnie opracowań z perspektywy historii filozofii, nie zaangażowanej doktrynalnie w spory natury eklezjalnej i teologicznej.

Należy zatem, w moim przekonaniu, pochylić czoła przed zadaniem, którego podjął się Jacek Zieliński, zbierając różnorodne wątki tematyczne, leżące lub potencjalnie leżące u podstaw późniejszej teorii stworzenia. Na wstępie mojej refleksji nad książką, muszę stwierdzić, że autor wnikliwie i szeroko bada problem, wykazując się erudycją i znajomością tematu. W swoich badaniach posługuje się literaturą źródłową oraz literaturą przedmiotu w różnych językach i dziedzinach naukowych. Swobodnie porusza się po tekstach filozofów greckich, literaturze biblijnej i pozabiblijnej, judaistycznej oraz chrześcijańskiej proweniencji. Zieliński niejednokrotnie pozwala sobie na dygresyjny tok wywodu, ubogacając wątkami pobocznymi główną linię argumentacyjną. Wszystko to sprawia, że choć lektura książki nie zawsze należy do najłatwiejszych, to jednak autor z dużym znawstwem wprowadza czytelnia w niezwykły świat kształtowania się teologii chrześcijańskiej $\mathrm{w}$ jej kosmologicznym wymiarze w pierwszych wiekach naszej ery.

We wstępie pracy autor wskazuje na znaczenie koncepcji creatio ex nihilo, odwołując się przede wszystkim do procesu hellenizacji, a tym samym, ufilozoficznienia postbiblijnej myśli chrześcijańskiej. Podkreśla, w jaki sposób myśliciele wczesnochrześcijańscy, wywodząc się w dużej mierze z kręgów greckich, adaptowali w swojej pracy koncepcje filozoficzne, aparat kategorialny oraz metodologię filozofów wraz z ich założeniami hermeneutycznymi. W jakimś sensie mogli opierać się na wypracowanej metodzie w żydowskim środowisku aleksandryjskim, gdzie Arystobul, Arysteasz, Filon Aleksandryjski czy Septuaginta, wyznaczali kierunki hellenizacji tradycji semickiej, czy to na poziomie filologicznym, czy koncepcyjnym i metodologicznym. Równocześnie autor wskazuje na szereg nowych koncepcji wypracowanych przez myślicieli chrześcijańskich w pierwszych wiekach naszej ery, z których teoria creatio ex nihilo bez wątpienia pełni znaczącą rolę. We wprowadzeniu autor ponadto omawia strukturę pracy, opowiadając się za diachronicznym studium tradycji filozoficznej, biblijnej, judaistycznej i chrześcijańskiej, wyjaśnia metodologię, rozróżniając między metodą genetyczną (sola scriptura), którą preferuje, i porównawczo-kontekstualną (dogmatyczną), którą traktuje jako drugorzędną, oraz stawia cele, które chce osiągnąć. Twierdzi (s. 47), że przede wszystkim pragnie ,zrekonstruować nauczanie apologetów II wieku o relacji między Bogiem rozumianym jako Stwórca i Zachowawca a stworzonym światem i człowiekiem" oraz odpowiedzieć ,na pytanie [...] czy możemy mówić o wpływie filozofii starożytnej na rozwój chrześcijańskiej doktryny creatio ex nihilo". Cele te autor chce osiągnąć przez analizę koncepcji Boga i początku świata w myśli greckiej, namysł nad problemem stworzenia w myśli biblijnej oraz rekonstrukcję poglądów apologetów greckich.

Wprowadzenie w tego typu książce ma - w moim przekonaniu - kluczowe znaczenie dla późniejszego wywodu, tak jeśli chodzi o kwestie zarówno metodologiczne, jak i merytoryczne. Autor wprost wskazuje, w jaki sposób zamierza prowa- 
dzić czytelnika w swoim wywodzie. Biorąc to pod uwagę, muszę wyrazić pewien żal, że autor ani we wstępie, ani nigdzie indziej w pracy nie zamieszcza expressis verbis pełnej definicji koncepcji creatio ex nihilo, jakkolwiek twierdzi, że jest ona kluczowa dla myśli chrześcijańskiej w jej historycznym i współczesnym wymiarze. Nigdzie w monografii nie znajdziemy pełnego ujęcia teorii, wskazania jej odmian i aberracji, ewolucji w historii i współczesnych odniesień. Szkoda, taka jednoznaczna definicja koncepcji pozwoliłaby czytelnikowi zrozumieć wprost sposób ujęcia problemu przez autora i zobaczyć główne stadia ewolucji teorii w pierwszych wiekach, na drodze do jej dojrzałej, doktrynalnej postaci. Podobnie, pewne zdziwienie wywołuje fakt, że autor we wstępie wydaje się deprecjonować gnostycyzm (s. 19). Powstaje wszakże pytanie, czy dialog z gnostykami nie mógł wpłynąć na takie a nie inne ujęcie koncepcji stworzenia w myśli chrześcijańskiej. Czyż Augustyn z Hippony nie dookreślił swojego stanowiska co do teorii creatio w dyskusji z późniejszymi manichejczykami, których przekonania kosmologiczne zbieżne były z koncepcjami gnostyckimi?

Rozdział pierwszy pracy Zieliński poświęca omówieniu problemu stworzenia świata w tradycji filozoficznej. Swój wywód rozpoczyna od analizy eposu Hezjoda, by następnie przejść do presokratyków: jońskich filozofów przyrody, Heraklita, Ksenofanesa i Anaksagorasa. W słuszny sposób zauważa, że creatio ex nihilo nie istnieje w tradycji greckiej ani w micie, gdzie w taki czy inny sposób funkcjonuje jakiś rodzaj prasubstancji, ani w filozofii, gdzie albo na wzór mitu filozofowie (Milezyjczycy) odwołują się do preegzystującej arche-zasady, albo podkreślają wieczność świata, choćby w formie koncepcji wiecznego powrotu (na przykład Heraklit czy Empedokles). Równocześnie autor monografii analizuje problem Boga w tradycji filozoficznej, wskazując na model bóstw immanentnych światu, zgodnie z wzorcami nakreślonymi przez mitografów oraz rodzącej się koncepcji Boga transcendentnego wobec świata czy świadomości człowieka, tak jak kreśli swoją teologię Ksenofanes z Kolofonu. Wątki te rozwijają filozofowie klasyczni jak Platon czy Arystoteles oraz myśliciele hellenistyczni jak stoicy czy medioplatonicy, gdzie religijny wymiar filozofii staje się coraz bardziej znaczaccy. Bez względu jednak na przyjęty model filozoficzny, tradycja grecka nie dopuszcza, jak zauważa Zieliński, żadnej formy creatio ex nihilo. Jeśli w myśli Hellady mamy do czynienia z jakimś modelem creatio, jest to zawsze proces twórczy, porządkujący jakąś preegzystentną arche-zasadę lub materię, nie akt stwórczy w sensie ex nihilo. Paradygmatyczny jest tutaj model nakreślony przez Platona w dialogu Timajos, gdzie quasi-boski Demiurg porządkuje w sposób matematyczny świat zmysłowy, wzorując się na doskonałym świecie idei.

Rozdział ten wydaje się bardzo ważny dla późniejszego wywodu autora. Kreśli on podstawy, do których Zieliński będzie wielokrotnie odwoływał się w dalszej części swojej pracy, równocześnie proponuje strukturę analizy w formie trzech elementów: Bóg - świat - stworzenie. Należy zauważyć, że autor bardzo kompleksowo podchodzi do analizy tradycji filozoficznej. Być może zbyt kompleksowo? Być może nie zaszkodziłaby troszeczkę większa selekcja materiału, dzięki czemu rozdział zyskałby na czytelności. Jeśli jednak autor tak szeroko podchodzi do problemu, trudno nie zadać pytania, dlaczego pomija filozofów z Elei. Wydaje się, że 
ontologiczne ustalenia Parmenidesa (byt jest a nie-byt nie jest) oraz jego eleackich następców są kluczowe w kwestii greckiego modelu stworzenia i zasady: nihil ex nihilo. Ich konsekwencją w dużej mierze są modele stworzenia takich myślicieli jak Empedokles, Platon czy filozofowie stoi. Nie mogę również tutaj nie odnieść się do metodologicznych ustaleń autora. Otóż w rozdziale wstępnym dokonał on rozróżnienia między metodą genetyczną i kontekstualno-porównawczą, stawiając wyżej tą pierwszą - sola scriptura, a drugą, dogmatyczną, ujmując jako dopełnienie analizy problemu. Rzecz wydaje się bardzo ważna i trudno się nie zgodzić z takim właśnie podejściem badawczym. Czy jednak jest ono możliwe do zastosowania przy tak skąpym materiale źródłowym, jak zachowane teksty wczesnych filozofów greckich, szczególnie, że nie są one sednem pracy Zielińskiego? Nie sądzę, dlatego za w pełni uzasadniony uważam fakt, że autor pozostaje jednak — przynajmniej w tym rozdziale - przy metodzie kontekstualno-porównawczej, odnosząc się do konkretnych tekstów filozofów jako ilustracji swoich tez. Przykładem może być analiza myśli Platona (s. 97-102), w której autor prezentuje konserwatywne stanowisko jeśli chodzi o odczytanie koncepcji idei i ich relacji ze światem gignetycznym. Wydaje się, że u podstaw analizy Zielińskiego kryje się określona, uprzednio przyjęta interpretacja ontologii platońskiej. Jest to jak najbardziej zrozumiałe, ale niezgodne z przyjętymi w książce założeniami metodologicznymi. Być może odpowiednie ujęcie metodologii pracy w części wstępowej byłoby pomocne?

$\mathrm{W}$ rozdziale drugim autor dokonuje analizy problemu stworzenia w tradycji judaistycznej, przy czym skupia się na Starym Testamencie (s. 129-145) i judaizmie hellenistycznym, w którym znaczącą rolę przypisuje Filonowi Aleksandryjskiemu. W interesujący sposób wprowadza rozdział i kreśli wątki koncepcji creatio ex nihilo. Kontynuując wywód, autor dobrze dokonuje rozróżnienia między myślą grecką i semicką, wskazując na transcendencję Boga wobec świata w tradycji biblijnej, szczególnie w jej późniejszych warstwach redakcyjnych. Analizując pierwsze wersety Biblii, fragment z Drugiej Księgi Machabejskiej $(7,28)$ oraz teksty Filona Aleksandryjskiego wskazuje, że trudno jest się doszukać jednoznacznych stwierdzeń o creatio ex nihilo w tradycji judaistycznej. Biblia hebrajska i Księga Machabejska są co najmniej niejednoznaczne, Filon zaś przyjmuje bardziej platoński niż tradycyjnie judaistyczny model stworzenia. Wnioski te wydają się jak najbardziej uprawnione, a analizując myśl Filona Aleksandryjskiego, Zieliński wykazuje się głęboką znajomością filozofii judaistycznej przełomu er.

Tym niemniej przy lekturze rozdziału, trudno nie zadać pytania, dlaczego autor książki skupia się przede wszystkim na pierwszym wersecie, pierwszego rozdziału Księgi Rodzaju. Jest wiele innych tekstów w Starym Testamencie (na przykład Ps 33,6; Ps 90,2; Ps 121; Ps 139; Jer 32,17; Iz 40,28; Am 9,60), które dotykają problemu stworzenia świata i wątków pobocznych. Teksty te są ważne w rekonstrukcji biblijnego zrozumienia początku świata i dobrze byłoby zobaczyć, w jaki sposób odnoszą się do inicjalnego bereszit w Księdze Rodzaju.

W swojej analizie Starego Testamentu Zieliński odwołuje się do historyczno-krytycznej metody źródeł J, E, D, P rozwiniętej na przełomie XIX i XX wieku przez Welhausena, Gunkela, a później Gerharda von Rada. Krytyka źródeł stanowi wciąż bardzo ważne narzędzie w rekonstrukcji i analizie tekstu biblii hebrajskiej, 
zazwyczaj jednak uzupełniana jest ona sukcesywnymi metodami krytycznymi, w szczególności krytyką redakcji i krytyką tradycji oraz zajmującą coraz bardziej prominentne miejsce w studiach nad Biblią, krytyką retoryczną. Z perspektywy krytyki redakcji czy krytyki retorycznej zestawienie opisów stworzenia może wyglądać inaczej, niż przy użyciu głównie mechanistycznej identyfikacji tekstu ze środowiskiem jahwistycznym (J), elohistycznym (E), deuteronomistycznym (D) czy kapłańskim (P), ukształtowanym dopiero po powrocie z niewoli babilońskiej, w czasie tak zwanej „drugiej świątyni jerozolimskiej”. Ciekaw jestem, jakie cele retoryczne odczytuje autor książki w zestawieniu pierwszego (Rdz 1 — źródło kapłańskie) i drugiego (Rdz 2 - źródło jahwistyczne) opisu stworzenia, i jak one rzutują na późniejszą narrację biblijną w odniesieniu do historii początku.

Rozdział trzeci monografii Zielińskiego skupia się na myśli wczesnochrześcijańskiej. Autor wskazuje tutaj na judaistyczne korzenie chrześcijaństwa, równocześnie zaś podkreśla proces hellenizacji, który rozpoczął się bardzo wcześnie w tradycji naśladowców Chrystusa. W swojej analizie problemu stworzenia, autor odnosi się do Septuaginty, greckiego tłumaczenia Starego Testamentu, które zwyczajowo wykorzystywali autorzy nowotestamentalni. De facto, z czasem Septuaginta została niejako zawłaszczona przez chrześcijan, tak że środowiska żydowskie zaczęły posługiwać się innymi przekładami, na przykład wersją Akwili. Rozważając problem stworzenia w Nowym Testamencie, Zieliński przywołuje teksty z Listu do Rzymian (4, 17) i Listu do Hebrajczyków $(11,3)$. Pytaniem otwartym pozostaje odniesienie do innych tekstów Nowego Testamentu, traktujących o stworzeniu, które jednak nie zostają omówione przez autora książki. Jednakowoż ważny jest w niniejszej dyskusji List do Kolosan 1, 15-20, prolog Ewangelii Jana czy 2 List Piotra 3, 5, który wręcz sugeruje ukształtowanie świata z już istniejącego tworzywa. Teksty te odnoszą się bezpośrednio lub pośrednio do takich fragmentów Starego Testamentu jak Ps 33, 6 czy Ps 148, 5. Jakkolwiek selektywny w swojej analizie tekstów nowotestamentowych jest autor monografii, uzasadniony jednak wydaje się jego wniosek o niejednoznacznym charakterze nauczania Nowego Testamentu o stworzeniu świata oraz niekwestionowalne wskazanie, że Bóg jest absolutnym źródłem i przyczyną istnienia całokształtu rzeczywistości.

Podobnie jak w rozdziale pierwszym książki, tak i tutaj niekiedy dominuje - takie przynajmniej mam wrażenie - dogmatyczne (metoda kontekstualno-porównawcza), a nie genetyczne (sola scriptura) odczytanie Pisma, mimo wskazań metodologicznych autora we wstępie monografii. Za przykład może posłużyć podsumowanie dotyczące chrystologii biblijnej. Na stronie 183 autor stwierdza: „Pierwotne chrześcijaństwo nie ujmowało Chrystusa ani jako preegzystującą boską myśl (Logos) ani w duchu subordynacjonizmu jako hipostazę, stanowiącą pomost między transcendentnym Bogiem a upadłym, grzesznym i zmysłowym światem". Niemniej jednak w Nowym Testamencie Chrystus przedstawiany jest niekiedy jako preegzystujący Logos (na przykład prolog Ewangelii Jana 1,1 nn). Równocześnie niejednokrotnie odczytać można subordynacjonizm w nowotestamentalnych relacjach Ojciec-Syn. Za przykład może posłużyć klasyczny tekst z I Listu do Koryntian 15, 24-28: „Potem nastanie koniec, gdy [Syn] odda władzę królewską Bogu Ojcu, gdy zniszczy wszelką zwierzchność oraz wszelką władzę i moc. Bo On 
musi królować, dopóki nie położy wszystkich nieprzyjaciół pod stopy swoje. A jako ostatni wróg zniszczona będzie śmierć. Wszystko bowiem poddał pod stopy jego. Gdy zaś mówi, że wszystko zostało poddane, rozumie się, że oprócz tego, który mu wszystko poddał. A gdy mu wszystko zostanie poddane, wtedy też i sam Syn będzie poddany temu, który mu poddał wszystko, aby Bóg był wszystkim we wszystkim" (tłum. Biblia Warszawska).

Rozdział czwarty książki Zielińskiego został zatytułowany Prawda o stworzeniu świata według apologetów. Stanowi on studium dialogu apologetów z autorami niechrześcijańskimi — poganami, swego rodzaju świadectwo dialektycznego rozwoju myśli chrześcijańskiej w zetknięciu ze światem niesemickim. Autor z dużą erudycją opisuje ewolucję nauczania chrześcijańskiego przez ojców apostolskich, apologetów i wczesnych ojców Kościoła, wskazując na różne emfazy poszczególnych autorów i ich stosunek do świata pogańskiego. Tutaj również autor podkreśla różne strategie apologetyczne omawianych autorów chrześcijańskich, tak jeśli chodzi o krytykę politeizmu świata helleńskiego, jak i demonologię grecką. Arystydes, Justyn Męczennik, Atenagoras, Teofil jednoznacznie wskazują na wyższość koncepcji jednego Boga nad popularnym panteonem bóstw. Czyż Platon, Arystoteles, Stoicy czy nawet pitagorejczycy i tragicy greccy nie bronili takiej teorii? Podobnie przedstawia się kwestia bytów duchowych, demonów, aniołów. To, co Grecy przeczuwali w swoich pismach, tradycja chrześcijańska dookreśla, przypisując siłom zła (Justyn Męczennik) systemy fałszu, naśladujące prawdę Boga. Podobnie jak we wcześniejszych rozdziałach, autor ze znawstwem i swobodac porusza się tutaj po niełatwych meandrach filozofii i teologii oraz buduje interesujący obraz kształtującej się z wolna chrześcijańskiej refleksji teologicznej pierwszych wieków w kontekście wyzwań społecznych, kulturowych czy lingwistycznych.

Na szczególną uwagę w tym rozdziale zasługuje passus poświęcony Ireneuszowi z Lyonu (s. 197-201), w którym Zieliński wskazuje na jego koncepcję stworzenia bliską później wypracowanej teorii creatio ex nihilo. Dlaczego jednak Ireneusz nie został ujęty we wstępie przez autora w gronie zapowiadanych kluczowych apologetów greckich (s. 29-46), pozostaje dla mnie pytaniem otwartym. Wszak jest on zaliczany do grona apologetów, pisał w języku greckim, odnosił się do filozofii greckiej, rozwijał teorię creatio i zbliżał się do koncepcji stworzenia z niczego. Jakkolwiek nie zostaje on zapowiedziany w części metodologiczno-wstępowej pracy, to jednak Jacek Zieliński dobrze kreśli jego wkład w rozwój chrześcijańskiej teorii stworzenia.

Finalny, piąty rozdział monografii zajmuje się problemem pochodzenia świata w pismach apologetów II wieku. W rozdziale tym autor rozważa problem Boga, w jakim stopniu jest on ujmowany jako Stwórca, w jakim zaś jako ten, który porządkuje preegzystentny materialny substrat (s. $279 \mathrm{nn}$ ). Następnie podejmuje problem materii i zagadnienie jej odwieczności (s. $305 \mathrm{nn}$ ). W końcu skupia się na kwestii Logosu (s. 328-352) jako pośrednika między transcendentnym Bogiem a zdeprawowanym — jednak stworzonym przez Boga — światem (s. 352-382). W rozdziale tym autor ponownie podkreśla proces kontekstualizacji myśli filozoficznej w środowisku chrześcijańskim oraz chrześcijaństwa w zetknięciu ze światem filozoficznym. Wskazuje jednak, że jakkolwiek animatorzy myśli chrześcijańskiej gotowi byli adaptować 
formy filozoficzne oraz metodologię filozofów, to jednak wierni byli fundamentalnym treściom biblijnym. Jedną z podstawowych prawd było ich przekonanie o tym, że „absolutną oraz jedyną przyczyną, dzięki której istnieje kosmos [...] był stwórczy, całkowicie wolny akt jedynego, odwiecznego oraz transcendentnego wobec świata Boga" (s. 279). W kontekście takiego stanowiska, powstaje jednak — zdaniem Zielińskiego — podwójny problem:

1. jak z owym aktem creatio można utożsamić obecność Logosu, skoro Bóg jest jedyną przyczyną stwórczą,

2. jak pogodzić twierdzenia o Bogu jako jedynej przyczynie stwórczej i wieczności materii.

Jak wskazuje Zieliński, pierwszy problem został rozwiązany przez doktrynę trynitarną, zgodnie z którą istnieje jeden co do natury — ousia Bóg w trzech osobach - hypostaseis. Drugi problem rozwiązywała koncepcja creatio ex nihilo. Tylko Bóg jest przyczyną zaistnienia świata, tylko Bóg również jest odwiecznym, wszechmocnym bytem. Materia jest produktem stwórczej mocy Boga. Rozwiązania powyższe, w sensie przynajmniej zalążkowym, możemy odczytać — zdaniem autora monografii — w pismach apologetów. Chrystologia już pod koniec II wieku zaczyna nabierać ortodoksyjnych kształtów (Justyn Męczennik, s. 337), a wstępne postaci koncepcji creatio ex nihilo można odczytać już w pismach Tacjana i Teofila, jakkolwiek Atenagoras, Arystydes czy Justyn mogą wciąż utrzymywać bardziej platoński model stworzenia świata. Tacjan i Teofil opowiadają się, zdaniem Jacka Zielińskiego, za podwójnym modelem creatio, według którego Bóg najpierw stwarza materię, następnie zaś kształtuje ją przez logos zgodnie z zawartymi w nim wzorcami (logoi spermatikoi). Zwieńczeniem tak stworzonego świata jest człowiek, korona stworzenia, któremu podlegają wszelkie inne porządki bytów. Świat jawi się Atenagorasowi jako wspaniały pałac, piękny instrument, którego konstruktorem jest Bóg, a użytkownikiem człowiek (s. 368).

W podsumowaniu dr Zieliński zbiera główne wątki poruszane w pracy i ponownie wskazuje, że podstawy koncepcji creatio ex nihilo odnaleźć można w pismach apologetów II wieku. Jakkolwiek dokonywali oni kontekstualizacji myśli chrześcijańskiej w zetknięciu ze światem pogańskim, wykorzystując metodologię, koncepcje i aparat kategorialny filozofów Hellady, to jednak, w swojej tytanicznej pracy, byli w stanie położyć podwaliny wielu oryginalnych doktryn chrześcijańskich. Teoria creatio ex nihilo była bez wątpienia jedną z nich.

Podsumowując niniejsze omówienie książki Jacka Zielińskiego Koncepcja creatio ex nihilo w myśli Apologetów greckich II wieku, mógłbym wskazać kilka metodologicznych niedociągnięć czy uwag natury merytorycznej. Wszystko to jednak są pytania i uwagi drugorzędne. Nie ulega kwestii, że podjęty problem jest ważny z perspektywy zarówno teologicznej, filozoficznej, jak i historycznej. Praca Zielińskiego zapełnia ważną lukę na polskim rynku wydawniczym. Autor jest znawcą literatury i problematyki wczesnochrześcijańskiej. Z dużą erudycją i swobodac potrafi przeprowadzić wywód dotyczacy koncepcji creatio ex nihilo, przemierzając niełatwe ścieżki filozofii greckiej, tekstów religijnych judaistycznej i chrześcijańskiej proweniencji oraz literatury wczesnych pisarzy chrześcijańskich. W swoim wywodzie kreśli interesujący obraz świata starożytnego, w którym teologiczna re- 
fleksja chrześcijańska stawiała pierwsze kroki i niejako po omacku szukała rozwiązań, które pozwoliłyby jej opisać całokształt rzeczywistości z perspektywy objawienia zawartego w Piśmie. Należy wszak zauważyć, że w II wieku naszej ery takie późniejsze filary ortodoksji chrześcijańskiej jak kanon pism Nowego Testamentu, sukcesja apostolska czy nawet wyznania wiary w syntetyczny sposób ujmujące wczesnochrześcijańskie doktryny istniały co najwyżej w formie zalążkowej. Z konieczności więc animatorzy myśli chrześcijańskiej, w tym apologeci II wieku, korzystali z ustaleń zarówno uczonych judaistycznej proweniencji, jak i filozofów greckich, którzy podobny proces pokonywali wieki wcześniej. W swojej książce Zieliński w fascynujący sposób kreśli ów obraz przez pryzmat fundamentalnej w swym znaczeniu koncepcji creatio ex nihilo. Mam nadzieję, że niniejsza książka doczeka się w niedługim czasie kontynuacji.

\section{Bibliografia}

św. Augustyn, Pisma egzegetyczne przeciw manichejczykom, tłum. J. Sulowski, Warszawa 1980.

św. Tomasz z Akwinu, Summa contra gentiles. Prawda wiary chrześcijańskiej w dyskusji z poganami innowiercami i bładzacymi, tłum. Z. Włodek, W. Zega, Poznań 2003.

Zieliński J., Koncepcja creatio ex nihilo w myśli Apologetów greckich II wieku, Wrocław 2013. 